\title{
How to Read Wittgenstein's Later Works with Gada- merian Ontological Hermeneutics on the Subject of Learning Color Concepts?
}

Renk Kavramların Ö̆grenme Hususunda Wittgenstein’ın Geç Dönem
Eserleri Gadamerci Hermenötik Bağlamda Nasıl Okunur?

ABDULLAH BAȘARAN

Stony Brook University

Received: 03.IO.I4 |Accepted: I4.I2.I4

\begin{abstract}
Even though there is an ineluctable abyss between Analytic and Continental Philosophy, it is not hard to argue that in his later works Ludwig Wittgenstein draws a closer philosophical attitude to the latter in terms of that the notions developed by him, such as language-games, family resemblances, meaning-in-use or rule-following, apart from his earlier nomological approach to language, leave room for various understandings and uncertainty in language. In the present work, my primary task is to concentrate on the close relationship between the Wittgenstein's notion of family resemblances and Gadamer's idea of the fusion of horizons. But both philosophers, coincide in criticizing the authority of the Cartesian subject and private language and in allowing different understandings and uncertainty in language. Starting from this point of view, the linguistic turn, I will turn my remarks on the question how we learn color concepts since the structure of these concepts radically differs from the words that are able to subject to ostensive definitions. This last section will also offer a hermeneutical reading of Wittgenstein's notion of family resemblances.
\end{abstract}

Keywords: Wittgenstein, Gadamer, color concepts, languagegames, hermeneutics.

凹 Abdullah Bașaran, Master $\ddot{g} g r$.

Stony Brook University, College of Arts and Sciences, Department of Philosophy $\mid$ II794375o, Stony Brook, NY, USA | maaveraa@gmail.com 
"We find that connects all the cases of comparing is a vast number of overlapping similarities, and as soon as we see this, we feel no longer compelled to say that there must be some one feature to them all. What ties the ship to the wharf is a rope, and the rope consists of fibres, but it does not get its strength from any fibre which runs through it from one end to the other, but from the fact that there is a vast number of fibres overlapping." ( $\mathrm{BrB}$ I92).

\section{Why A Comparison of Wittgenstein and Gadamer?}

\section{I.I. Wittgenstein Practices Hermeneutics}

Before we compare and contrast the concepts of language-games and horizons, let me explain why it is needed for such a philosophical study.

Wittgenstein, in his works after Tractatus period, dramatically draws near to Gadamer's ideas on linguisticality shown in the last three parts of Truth and Method. In this context, we see Wittgenstein eliminates his earlier thought on language. As it is known, in Tractatus, he declares in seven propositions language undoubtedly represents the reality. Succinctly put, language pictures reality. This argument, which became the core of the entire Analytic and positivist traditions in a short time, will be criticized by himself in his lecture notes in Cambridge. Wittgenstein here builds a radically new philosophy that will reach the peak with his posthumous work Philosophical Investigations (von Wright, 200I: I3).

In this new philosophy, Wittgenstein realizes that the picture theory, which is the main argument of Tractatus, is insufficient to explain the nature of language since language includes not only names which can be defined ostensively, but also expressions such as "that" or "there" and different concepts like numbers and colors. Here Wittgenstein offers the notion of "language-games" in order to understand the complex structure of language. ${ }^{\mathrm{I}}$ By doing so, Wittgenstein introduces not a new doctrine or analytic explanations, but a method of thought (PI I09, 126). For instance, unlike seven commandments of Tractatus, he leaves many questions open while discussing dialectically with his interlocutor. Moreover, he gives a lot of examples from language of daily life in order to para-

\footnotetext{
I Since I will scrutinize this issue in detail later, here I will not dilate upon his thoughts.
} 
phrase his arguments. Even the event that he found the idea of "languagegames" is from his daily observation (Malcolm, 200I: 55).

Like many philosophers from the Continental philosophy, Wittgenstein now agrees with the idea that language is praxis. It is part of activity and a form of life ( $P I$ 23). Meaning depends upon its context and use in situations. Without context or use, it can never be mentioned "the" meaning of a word. Going further, Wittgenstein admits polysemy in meanings, that is, there are various understandings and different usages in language. He remarkably says, "From its seeming to me -or to everyoneto be so, it doesn't follow that it is so." $\left(O C_{2}\right)$.

This critique of the supreme subject drawn by Cartesian thought significantly overlaps with the proposals of the hermeneutic tradition, particularly of Gadamer who challenges this issue in his magnum opus Truth and Method. As Chris Lawn states,

In remarkably similar ways Gadamer and Wittgenstein question the authority of the Cartesian subject as the epicentre of meaning... An intersubjective dimension shows how ordinary language is sustained by consensus and publicly available agreements and not the inner reflections of the thinking subject. Gadamer and Wittgenstein work through the philosophical consequences of ditching Cartesianism, effectively threatening as it does the very enterprise of philosophy-as-metaphysics (Lawn, 2006: xiii).

From what has been discussed so far, although it is impossible to consider Wittgenstein as a hermeneutician, we may say that while dealing with language in use and daily life in his later works, he noticeably practices hermeneutics.

\subsection{There are Many Similarities between Wittgenstein and Gadamer}

Besides that both philosophers give primacy to language in his works, the concepts used by Wittgenstein and Gadamer also share some similarities. The most significant one is of course that Wittgenstein develops the very idea of language-games (Sprachspiele) in order to analyze children's learning of their own language, whereas Gadamer uses play (Spiel) as the key term explaining the nature of language. Both philosophers here use games or plays as a practical activity. This leads us to another similarity: The critique of private language. Simply put, while Witt- 
genstein disagree with the idea of private language over his main example of pain, Gadamer makes an analogy between play and language in terms of that play is more than the actions of players. For Gadamer language presupposes solidarity (Lawn, 2006: 106). In a conversation, he also indicates he agrees with Wittgenstein's argument, "no private language" (Gadamer, 200I: 56). Furthermore, there are also similarities in between Wittgenstein's ideas of "language in use" and "meaning in context" and the notion of "tradition" rehabilitated by Gadamer; and between the former's "language-games" and the latter's "horizon".

\subsection{Gadamer Reads Wittgenstein's Works}

Despite the fact that Gadamer overlooks Wittgenstein in his early works, then he admits "language-games" is very similar to his concept of prejudice. In "Foreword to the Second Edition" of Truth and Method, he says, "Wittgenstein's concept of "language games" seemed quite natural to me when I came across it" (Gadamer, 20I3: xxxii, I3n). He also mentions Wittgenstein's language games of our daily language in order to elucidate his concept of play (Gadamer, 2013: 582). After Truth and Meth$o d$, Gadamer remarkably leaves room for the philosophy of Wittgenstein in various articles. ${ }^{2}$ Here he is totally aware of closeness of Wittgenstein's later works to his hermeneutical project in terms of the intersubjectivity of language and the achievement of mutual understanding. In this regard, Linge succinctly states,

What Gadamer and Wittgenstein share in common, therefore, is the affirmation of the unity of linguisticality and institutionalized, intersubjectively valid ways of seeing. Furthermore, and more significantly, both of them stress that the rules of a language game are discovered only by observing its concrete use in interpersonal communication (Linge, 1976: xxxv).

\subsection{Hermeneutical Approach Requires to Reconcile These Two Philosophers}

The aim of this paper is to search for a harmony between Wittgenstein's family resemblances and Gadamer's notion of the fusion of horizons. Hence we believe that the present work must be suitable for the purpose of a hermeneutical task. As it can be predicted, that is not to say

2 Such as "The Nature of Things and the Language of Things", "The Philosophical Foundations of the Twentieth Century", and "The Phenomenological Movement" in Philosophical Hermeneutics. 
that showing the similarities between Wittgenstein and Gadamer, there will be a complete fusion of these two different thoughts. Rather being aware of the ground on which they stand, we will try to understand the former's works in accompany with the latter's ontological hermeneutics because we know that "a hermeneutically trained consciousness must be, from the start, sensitive to the text's alterity" (Gadamer, 2013: 282).

\section{Wittgenstein: Language-Games and Family Resemblances}

Philosophical Investigations famously starts with the critique of Augustinian picture of language, which argues, first, all words are names; second, learning a name is being told what it means; and third, learning a language is a matter of learning new words (Cavell, 2000: 24). As Wittgenstein formulates,

In this picture of language we find the roots of the following idea: Each word has a meaning. This meaning is correlated with the word. It is the object for which the word stands ( $P I$ I; cf. $B r B$ I79).

Here Wittgenstein raises the focal question: Learning nouns like "table", "chair", or people's names truly fits this picture. But what about number, colors, or pronouns like "there" and "this"? To use the example in the first paragraph of Philosophical Investigations, in "five red apples", what is the meaning of "red"? Here Wittgenstein does not think that Augustine is entirely wrong in his approaches on language that consists of a system of signs. But rather, Augustine's attempt is not sufficient to explain our language in use (Cf. Allison, I978: 95). In other words, explanations based upon ostensive definitions (like what "slab" means) cannot be suitable for every case. We can point at a book while saying its name, but we cannot point at its color regardless of the thing itself. That's why Wittgenstein seeks an exit door from ostensive or demonstrative explanations, drawn by Augustine's theory of representation in language, in favor of an expanded language including numerals, color samples, pronouns, and so on (BrB I82-3; PI 6, 8; McGinn, 2013: 45).

For Wittgenstein, the process of learning language is not an explanation but a kind of training ( $P I$ 5). He calls this various ways of training as "language-games":

In instruction in the language the following process will occur: the learner 
names the objects; that is, he utters the word when the teacher points to the stone. - And there will be this still simpler exercise: the pupil repeats the words after the teacher - both of these being processes resembling language.

And the process of naming the stones and of repeating words after someone might also be called language-games. Think of much of the use of words in games like ring-a-ring-a-roses.

I shall also call the whole, consisting of language and actions into which it is woven, the "language-game" $(P I 7)$.

Wittgenstein here claims that rather than grasping the whole meaning of a word or a concept since it is impossible to reach certainty or purity in language, ${ }^{3}$ a child witnesses different use of words precisely because even ostensive definitions are variously interpreted in every case ( $P I$ 28, 29, 97). ${ }^{4}$ As well as he learns different language-games, he becomes the master of language because these games allow him to see its different meanings in daily language and to encounter the network of similarities (PI 66; cf. $B r B$ I84-5). The child names things, he pronounces it, and repeats after his teacher. But when we want him to differ the shape of a thing from its color, or the number of items from items themselves, "we mean something different" in that case. Wittgenstein says,

[If] we look for two such characteristic mental acts as meaning the color and meaning the shape, etc., we aren't able to find any, or at least none which must always accompany pointing to color, pointing to shape, respectively. We have only a 'rough' idea of what it means to concentrate one's attention on the color as opposed to the shape, vice versa. The difference, one might say, does not lie in the act of demonstration, but rather in the surrounding of that in the use of the language $(B r B$ I83).

This passage summarizes significant points in Wittgenstein's idea of language-games: First, ostensive definitions are not able to draw a broader map of the nature of language. Second, we can only have a rough idea of such concepts. And finally, the meaning of a word is its use. The last con-

\footnotetext{
In On Certainty, he also equates the transcendent certainty with Spirit $(O C, 47)$.

4 In paragraph I07 of Philosophical Investigations, Wittgenstein poetically says, "We have got on to slippery ice where there is no friction and so in certain sense the conditions are ideal, but also, just because of that, we are unable to walk. We want to walk: so we need friction. Back to the rough ground!"
} 
sequence has a major importance: Each use has own different meaning (PI 43; BB I7I; OC 6I, 65). To put it briefly, "meaning has to do with the effectively practiced language game, i.e., the use of language in the context of a given empirical situation, where use is governed by systems of rules and conventional operations" (Allison, 1978: 97). This polysemy of meaning is in fact the gist of language-games. That the meaning of a word changes in each circumstance brings forth the network of similarities. That is to say, although meaning depends upon its use, each use resembles one another. Wittgenstein says,

Instead of producing something common to all that we call language, I am saying that these phenomena have no one thing in common which makes us use the same word for all, - but that they are related to one another in many ways (PI 65).

In this regard, the web of similarities between language-games that we use in our daily language, is called "family resemblances": "For the various resemblances between members of a family: build, features, color of eyes, gait, temperament, etc. etc. overlap and criss-cross in the same way." (PI 67; cf. PI I30).

To give an example, for we learn a game like chess, we are supposed to have already known what a game is, that the rule means in a game, and so on. We have already known something. Wittgenstein, however, never addresses only one way of learning of a game. We may watch a game and repeat it step-by-step. Or, the teacher tells us what each pieces work for, and we immediately compare it with checkers or go, and then we begin to play. Further, we just watch a game, and we can play without any explanation ( $B B$ 87-8). The point is that not only does Wittgenstein point out the obscure nature of language, he also shows us that when we learn something new, it is not exactly new for us (PI 89). We are familiar with it in virtue of that it does inevitably resemble to one of our preconceived ideas - though we are not able to rule over them.

The concept of family resemblance is indeed the ultimate response of Wittgenstein towards Augustine's oversimplification of the complex structure of language and towards the problem of universals which evidently subject to the endless craving for generality. However, he refrains from offering a single essence or model for all general concepts. Instead 
he proposes a rhizomatic structure for the nature of language ( $B B$ Io6, IO8; Stern, 2004: III-2; McGinn, 2013: 40; Forster, 20I3: 67, 87).

\section{Gadamer: Tradition, Prejudices, and the Fusion of Horizons}

In his magnum opus Truth and Method, Gadamer proposes an awareness of the historical consciousness as opposed to the obsession with objectivity and purity in language. That means we, beings thrown in the middle of time, are unavoidably situated by our own historicity, and the dialogue between us and tradition is ineluctable. That's why, according to Gadamer, tradition is not a thing we can get rid of (Gadamer, 200I: 45). Rather it constitutes our prejudices, our situation in history, and consequently our historical reality of being. No one can, therefore, speak of being objective while he lives along with tradition and his prejudices.

Here Gadamer follows Heidegger's ontology. The historical situatedness of the individual (Dasein), is properly known as "historicity". Dasein, according to Heidegger, is the being who belong to history (Heidegger, 2008: 27; cf. Gadamer, 2013: 287-9). Since there is no room for escaping this situation, Gadamer wants us to be aware of this situatedness rather than to overcome (Horn, 2005: 21, 32, 40; Lawn, 2006: 28).

The situation of the individual colors our historical account, that is, as Wachterhauser states, "our ability to order and make sense of our world" (Horn, 2005: 50). That is to say, as well as Dasein is not able to be out of himself, his belonging to history constitutes, determines, and even limits his being-in-the-world. In a word, our tradition historically and linguistically shapes us. That leads us to Gadamer's idea of the rehabilitation of the word 'tradition' because "[historical] consciousness happens within a context where the specific cultural past of tradition constantly operates" (Lawn \& Keane, 20II: 79).

For Gadamer, tradition is the main constituent of the historicity of existence. It is in fact not a burden for our reason and knowledge, but a legitimate source of experience and understanding. In contrast to the idea that tradition is barrier preventing us to reach objectivity and purity in language, he points out the impossibility of exclusion of tradition with regard to that the individual is already an integral part of his own past, history, and tradition. Rather the dialogue with the past in order to un- 
derstand the old and new experiences is unavoidable. As a brief consequence, the ground on which we stand is constituted by tradition. In his introduction to Gadamer's Philosophical Hermeneutics, Linge states,

The role of the past cannot be restricted merely to supplying the texts or events that make up the 'objects' of interpretation. As prejudice and tradition, the past also defines the ground the interpreter himself occupies when he understands (Linge, 1976: xv).

In this regard, each experience and understanding is completely and inevitably related to the past experiences. All process of praxis is but a chain of experiences representing the finitude of human experience and limits of understanding. The process of experience, however, according to Gadamer, has not linear but circular movement. With the help of Heidegger's interpretation (Heidegger, 2008: I88-95), Gadamer advances the hermeneutical circle. Just as the whole text is understood with the partial anticipatory movement of fore-understanding in hermeneutical reading of a text, so the understanding of a new experience is accomplished by our relation to tradition (Gadamer, 2013: 305-6).

Another significant move of Gadamer is to rehabilitate the concept of prejudice. Prejudice, gained the negative connotation by the Enlightenment and historicism, is a judgment preventing us to approach a problem as it is; and is in fact the main barricade for us get rid of tradition, of all kind of authorities, and of religion (Gadamer, 2013: 284-5). However, Gadamer embeds the term in the center of understanding. In this sense, because it cannot be thought apart from its relationship with tradition and the past, all understanding is pre-understanding and inevitably involves prejudices. That purports prejudgments constitute our basis of understanding and shape our questioning as much as our historicity and tradition color our being (Gadamer, 2013: 288-9).

Hereby we reach Gadamer's idea of horizons. It is clear that our historically effected consciousness comprising of our tradition and prejudices, unavoidably shapes our standpoint, the way we see the world, namely horizon. For Gadamer, the idea of horizon not only represents not only our historical situatedness and connectedness with tradition, but also emphasizes our linguisticality since language, in general terms, is the only way to communicate with people and texts. Gadamer says, 
The concept of "horizon" suggests itself because it expresses the superior breadth of vision that the person who is trying to understand must have. To acquire a horizon means that one learns to look beyond what is close at hand - not in order to look away from it but to see it better, within a larger whole and in truer proportion (Gadamer, 2013: 316).

The linguistic horizon, i.e., our standpoint in language, constantly and inevitably interacts because language presupposes a solidarity. Horizons inevitably fuse in every linguistic encounter (Lawn, 2006b: 29). This process of interaction, one's dialogue with the horizon of the past, of people, or of a text, is named by Gadamer as "the fusion of horizons". Even though it is impossible to say this hermeneutical task can never be finally completed, horizons indispensably fuses within another horizons due to the very fact that "all understanding is always the fusion of these horizons" (Gadamer, 20I3: 3I7). Therefore we can argue that all understanding is a retrospective relation between the present and the past experience. As Lawn summarizes,

The language through which we articulate the present resonates with the meanings from the past and they continue to be operative in the present; this gives a sense of what Gadamer means by "effective historical consciousness" (Lawn \& Keane, 2011: 53).

However, it is not true that one has own horizon does not mean he is stuck in his prison. Horizons are in fact open to change. That is to say, as long as prejudices we have interact with other horizons, they limit or extend the range of horizons in the linguistic base. What is more, where two horizons fuse, something constantly arises that did not exist before (Gadamer, 200I: 48; cf. 20I3: 422-3). In the next section, we will call this process unending learning.

\section{How Do We Learn Color Concepts? A Hermeneutical Reading of Wittgenstein's Later Philosophy}

In Philosophical Investigations and Remarks on Colour, Wittgenstein uses the concepts of "language-games" and "family resemblances" in order to understand the nature of color concepts. Following J.W. Goethe's contradictions to Newtonian theory of colors, Wittgenstein regards man's color perception as a phenomenological experience. But unlike 
Goethe, he aims to achieve a logic of color concepts, not a theory for colors ( $R C$ I.22). As long as some part of color concepts belongs to the subject itself, it is really hard to say we are able to have a theory of colors. That's why Wittgenstein mentions different geometries of colors passim in Remarks on Colour ( $R C$ I.65, III.3O, I23, 154). This differentiation leads us to propound there is not only way to name colors. Just as we give the meaning of a word in practice, so color concepts too are distinguished according to its use in a particular case. Here the question rises: So, "How do people learn the meaning of color names?" ( $R C$ III.6I).

As it can be predicted, Wittgenstein's response would be 'with language-games'. In The Blue Book, he says,

Language games are the forms of language with which a child begins to make use of words. The study of language games is the study of primitive forms of language or primitive languages ( $B B$ I05; cf. PI 6).

To illustrate, a child's process of learning color concepts is based upon training, not on ostensive definitions or explanations. The statement "Red 'is' ..." does not make sense in this circumstance. We point at a chair, and utter "this chair is red." Then we show the child a coffee table that is red. In another language-game, we give a color sample in order him to pick the correct square in a color table or a scale. According to Wittgenstein, the only way the child determines these two examples are 'red' or 'reddish' is to associate one with the other ( $P I 73 ; B B 87-8)$. Even if we do not know how we begin to make connections between concepts, we somehow distinguish one thing from another. ${ }^{5}$ That means we learn to use language in daily life. Accordingly, we use the colors before we learn their name. What is more, even if he does not know the word for "red", he has learned what a red thing "is".

As it is understand, it is not hard but impossible to find the beginning of learning. In this regard, we can say we are thrown at the middle of language; and in this thrownness, Wittgenstein's response to this complicated system is that we learn color concepts by recognizing resemblances between what we experienced in the past and what we are experiencing

5 Cavell suggests the leaps in language: "We don't know the meaning of the words. We look away and leap around." (Cavell, 2000: 24). 
now. As a result, experience is the ground of our own certainty, and we, people thrown, do not know where everything begins (OC 47I; PI 30, 89).

Throughout the process of this training, the only instrument enabling the to see the resemblance between one sample and another is his backgrounds and the context in the situation (PI 2I). As it can be remembered, for we learn chess, we have already known about what a game is or the meaning of rules in a game. To repeat it once more, when we learn something new, it is not exactly new for us. We are somehow familiar with it by means of that it inevitably resembles to one of our preconceived ideas (PI 89).

Here appears the close relationship between family resemblances and the idea of the fusion of horizons. In fact, what Wittgenstein calls background or context is corresponded by Gadamer with the notion of "tradition". To understand a new and different meaning of color is only accomplished by our relation to tradition (Gadamer, 2013: 305-6). The child, in every encounter with a new use of a color sample, links between his past experiences, that is tradition, with the new one. Thus the horizon on which he sees the world linguistically fuses with the horizon of the present language-game. Finally, at the end of this fusion, both one's horizon and language are simultaneously modified. ${ }^{6}$

\section{References}

Allison, D. B. (1978). Derrida and Wittgenstein: Playing The Game. Research in Phenomenology, 8 (I), 93-109.

Cavell, S. (2000). Excursus on Wittgenstein's Vision of Language. The Nerw Wittgenstein (eds. A. M. Crary \& R. J. Read). London: Routledge.

Forster, M. (2013). Wittgenstein on Family Resemblance Concepts. Wittgenstein's Philosophical Investigations: A Critical Guide (ed. A. Ahmed). Cambridge: Cambridge University Press.

Gadamer, H.-G. (200I). Gadamer in Conversation: Reflections and Commentary (ed. R. E. Palmer). New Haven: Yale University Press.

Gadamer, H.-G. (2013). Truth and Method (trans. J. Weinsheimer \& D. G. Mar-

${ }^{6}$ Here I will suggest that we can primitively read overlapping fibres, which is in the rope metaphor in the quotation at the beginning of the paper, as the fusion of horizons. 
shall). New York: Bloomsbury Academic.

Heidegger, M. (2008). Being and Time (trans. J. Macquarrie \& E. Robinson). New York: Harper Perennial.

Horn, P. R. (2005). Gadamer and Wittgenstein on the Unity of Language: Reality and Discourse without Metaphysics. Aldershot, Hants: Ashgate.

Lawn, C. \& Keane, N. (20II). The Gadamer's Dictionary. New York: Continuum.

Lawn, C. (2006a). Gadamer: A Guide for the Perplexed. London: Continuum.

Lawn, C. (2006b). Wittgenstein and Gadamer: Towards a Post-Analytic Philosophy of Language. London: Continuum.

Linge, D. E. (1976). Editor's Introduction. Philosophical Hermeneutics. Berkeley: University of California Press.

Malcolm, N. (200I). Ludwig Wittgenstein: A Memoir. Oxford: Clarendon Press.

McGinn, M. (2013). The Routledge Guidebook to Wittgenstein's Philosophical Investigations. New York: Routledge.

Stern, D. G. (2004). Wittgenstein's Philosophical Investigations: An Introduction. New York: Cambridge University Press.

Von Wright, G. H. (200I). A Biographical Sketch. Malcolm, Ludwig Wittgenstein: A Memoir. Oxford: Clarendon Press.

Wittgenstein, L. (1968). Philosophical Investigations (trans. G. E. M. Anscombe). New York: The Macmillan Company.

Wittgenstein, L. (1977). Remarks on Colour (trans. L. L. McAlister \& M. Schattle). Blackwell Publishing.

Wittgenstein, L. (2009a). On Certainty (ed. L. Kaeppel). Major Works: Selected Philosophical Writings. New York: Harper Collins Publishers.

Wittgenstein, L. (2009b). The Blue Book (ed. L. Kaeppel). Major Works: Selected Philosophical Writings. New York: Harper Collins Publishers.

Wittgenstein, L. (2009c). The Brown Book (ed. L. Kaeppel). Major Works: Selected Philosophical Writings. New York: Harper Collins Publishers. 
Öz: Analitik ve Kıta Avrupası felsefesinde așılmaz bir uçurum varmış, gibi gözükse de, erken dönem felsefesindeki dile nomolojik yaklașımını bir kenara bırakacak olursak, Ludwig Wittgenstein'ın, geç dönem eserlerinde geliștirdiği dil oyunları, ailevi benzerlikler, kullanımdaki anlam ve kural takibi gibi kavramlar sayesinde dil içerisinde farklı anlayışlara ve değișkenliğe yer verdiği için, Kıta Avrupası felsefesine yakın bir felsefi tutum içerisinde olduğunu söylemek zor olmayacaktır. Bu çalışmada, benim de öncelikli amacım Wittgenstein'ın ailevi benzerlikler kuramı ve Gadamer'in ufukların kaynaşması düșüncesi arasındaki yakın ilișkiye odaklanmak olacak. Zira bu iki filozof, Kartezyen öznenin onulmaz otoritesi ve şahsî dil anlayıșının eleștirilmesi hususunda benzer tutumu sergiler. Bu noktadan yol çıkarak, asıl meselemiz olan renk kavramlarını nasıl öğrendiğimiz sorusuna yönelecek ve Wittgenstein'ın ailevi benzerlikler kuramına hermenotik bir okuma önerisinde bulunacağız.

Anahtar Kelimeler: Wittgenstein, Gadamer, renk kavramları, dil oyunları, hermenötik. 